\title{
Determination of Antioxidant Capacity of 2,6-Quinolinediol
}

\author{
Fevzi TOPAL ${ }^{1 *}$
}

\begin{abstract}
The compounds of the quinolone group have been widely used in the alive metabolism, paint and pharmaceutical industry. Therefore, various quinoline derivatives are synthesized and synthesis methods are developed. The synthesis of the quinoline compounds in the industrial field is formed in a separate area. 2,6-quinolinediol is derivative a quinoline. In this study, different bioanalytical methods such as reducing capacity by $\mathrm{Fe}^{3+}-\mathrm{Fe}^{2+}$ transformation method, $\mathrm{Fe}^{3+}-\mathrm{TPTZ}$ reducing capacity by FRAP method, $\mathrm{Cu}^{2+}-\mathrm{Cu}^{+}$reducing capacity by CUPRAC method, the ferric ions $\left(\mathrm{Fe}^{2+}\right)$ chelating activity by using bipyridyl reagent, DPPH, ABTS, DMPD radical scavenging activities, superoxide anion radicals $\left(\mathrm{O}_{2}{ }^{-}\right)$scavenging activity have been used. Also, Trolox, $\alpha-$ Tocopherol, BHA and BHT have been used as reference antioxidants. The $\mathrm{IC}_{50}$ inhibition value of the ABTS radical removal activity for this substance was calculated as $3.39 \mu \mathrm{g} \mathrm{mL} \mathrm{m}^{-1}$. Reference antioxidants such as trolox, BHA, $\alpha$-Tocopherol and BHT exhibited ABTS radical removal inhibitions at $2.59,4.44,7.07$ and $32.36 \mu \mathrm{g} \mathrm{mL}^{-1}$, respectively. Studies have shown that 2,6-quinolinediol is an effective antioxidant.
\end{abstract}

Keywords: 2,6-quinolinediol, Antioxidant activity, Radical scavenging

\section{2,6- Kinolindiol Bileşiğinin Antioksidan Kapasitesinin Belirlenmesi}

ÖZET: Kinolin grubu bileşikleri, canlı metabolizması, boya ve ilaç sektöründe geniş çapta kullanılmaya başlamıştır. Bu nedenle çeşitli kinolin türevleri sentezlenmekte ve sentez yöntemleri geliştirilmektedir. Endüstriel açıdan kinolin bileşiklerinin sentezi ayrı bir alan oluşturmaktadır. 2,6kinolindiol bir kinolin türevidir. $\mathrm{Bu}$ çalışmada; $\mathrm{Fe}^{3+}-\mathrm{Fe}^{2+}$ transformasyonu metoduna göre indirgeme kapasitesi, CUPRAK metoduna göre $\mathrm{Cu}^{2+}-\mathrm{Cu}^{+}$indirgeme kapasitesi, FRAP metoduna göre $\mathrm{Fe}^{3+}-\mathrm{TPTZ}$ indirgeme kapasitesi, bipiridil reaktifi kullanarak ferröz iyonları $\left(\mathrm{Fe}^{2+}\right)$ şelatlama aktivitesi, DPPH, ABTS, DMPD radikal giderme aktiviteleri ile süperoksit anyon radikalleri $\left(\mathrm{O}_{2}{ }^{-{ }^{-}}\right)$giderme aktivitesi gibi farklı biyoanalitikal metotlar kullanıldı. Ayrıca BHA, BHT, $\alpha$-tokoferol ve troloks referans antioksidan olarak kullanıldı. $\mathrm{Bu}$ madde için ABTS radikal giderme $\mathrm{IC}_{50}$ inhibisyon değeri $3.39 \mu \mathrm{g}$ $\mathrm{mL}^{-1}$ olarak hesapland. BHA, $\alpha$-Tocopherol, trolox, BHT ve gibi standart antioksidanlar, sirasiyla 2.59, 4.44, 7.07 ve $32.36 \mu \mathrm{g} \mathrm{mL}^{-1}$ olarak ABTS radikal giderme inhibisyonları sergiledi. Çalışmalar 2,6-kinolindiolün, etkili bir antioksidana sahip olduğunu açıkça göstermiştir.

Anahtar Kelimeler: 2,6-kinolindiol; Antioksidan aktivite; Radikal giderme

\footnotetext{
${ }^{1}$ Fevzi TOPAL (Orcid ID:0000-0002-2443-2372), Gumushane University, Gumushane Vocational School, Department of Chemical and Chemical Processing Technologies, Laboratory Technology Program, Gumushane, Turkey.

*Corresponding author: Fevzi TOPAL, e-mail: topalfevzi@hotmail.com 


\section{INTRODUCTION}

Oxygen has a special place in aerobic life. Because oxygen is the last electron acceptor in ATP production which is an important compound for living life (Davies, 1995). During the electron flow, unconjugated electrons are formed. These electrons create free radicals, causing various damages in the organism (Gulcin, 2012). The biggest dangers of free radicals are the unstable molecules. This is because they oxidize living and non-radical molecules with uncomplicated electron pairs (Gulcin, 2012; Topal, 2018). Due to lipid peroxidation, the membrane lipids have the greatest damage (Bursal et al., 2013).

ROS is produced at a certain level in healthy cells in live metabolism. They have the capacity to damage important biomolecules such as proteins, nucleic acids, carbohydrates, polyunsaturated fatty acids and lipids. They cause mutations by damaging DNA and RNAs. If they are not removed by ROS-effective cellular components, they can cause serious metabolic damage by stimulating radical chain reactions after damaging the protein, lipid and nucleic acids, and finally cellular biomolecules (Öztaşkın et al., 2015). As a result, ROS; It has been observed to cause more than 100 diseases such as heart attack, stroke, asterosclerosis, immunodeficiency syndrome, diabetes, cancer and malaria (Alho and Leinonen, 1999; Gulcin 2012). Antioxidants are substances that inhibit or stop oxidizing molecules. An antioxidant molecule should be able to prevent oxidation even at low concentrations. In addition, they protect living organisms from the damage of ROS. On the other hand, they are also the shield against chronic diseases (Taslimi and Gulcin, 2018). The terms antioxidant activity or antioxidant capacity may be used to indicate the antioxidant capabilities of food ingredients, but they are both different. Phenol derivatives prevented metabolic cholesterol oxidation. A wide range of synthetic antioxidants are available in the pharmaceutical, food, and cosmetic industries (Hudson, 1990; Eberhardt et al., 2000). But, the use of synthetic antioxidants was restricted to legal rules due to the suspicion of being carcinogenic and toxic (Wichi, 1988; Sherwin, 1990). Therefore, the interest in safer antioxidants is increasing for food applications and the trend towards natural antioxidants in consumer preferences has led to an acceleration of attempts to explore antioxidant sources (Gulcin, 2007).

Quinoline is a hetero ringed compound wherein a benzene ring and a pyridine are fused (Fessenden et al., 2001; Hart et al., 2011). The most important examples are quinoline and isoquinoline and are similar to naphthalene. Quinoline and isoquinoline rings are found in many natural compounds like quinine and papaverine (Hart et al., 2011). Quinoline derivatives have been attracted to scientific studies and pharmaceuticals due to their carcinogenic and mutagenic properties (Ökten et al., 2015).

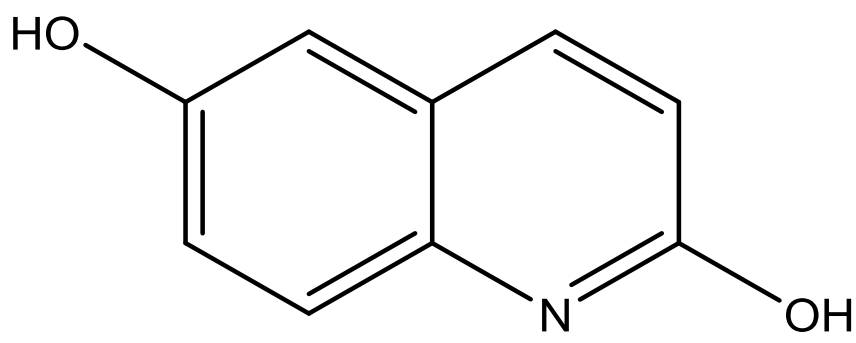

Figure 1. Chemical structure of 2,6-Quinolinediol 
In our article, we investigated the antioxidant activities and capacities of 2,6-quinolinediol using 8 different antioxidant methods. Considering the results, it is thought that it is a highly effective molecule and will contribute to new literature studies.

\section{MATERIALS AND METHODS}

\section{Ferric Ions $\left(\mathrm{Fe}^{2+}\right)$ Chelating Activity}

Ferric ions $\left(\mathrm{Fe}^{2+}\right)$ binding ability of 2,6quinolinediol was determined according to method of Dinis et al. (1994) with minor modification (Gulcin et al., 2004). This method, $\mathrm{Fe}^{2+}$ capacity of 2,6-quinolinediol was recorded at $562 \mathrm{~nm}$. $0.6 \mathrm{mM} \mathrm{FeCl}_{2}$ were added 2,6quinolinediol 10 and $20 \mu \mathrm{g} \mathrm{mL}^{-1}$ concentrations in methanol. $5 \mathrm{mM}$ of ferrozine solution were added this mixed. At $25{ }^{\circ} \mathrm{C}$ for $10 \mathrm{~min}$, the solution was mixed and incubated. Finally; absorbance values were measured spectrophotometrically at $562 \mathrm{~nm}$ (Gulcin, 2010).

\section{Cupric Ions $\left(\mathrm{Cu}^{2+}\right)$ Reducing-CUPRAC Assay}

Cupric ions $\left(\mathrm{Cu}^{2+}\right)$ reducing ability was used as a second reducing method for 2,6quinolinediol. $\mathrm{Cu}^{2+}$ reducing capability was done according to the method described by Apak et al. (2004) with slight modification (Gulcin et al., 2011). Cupric ions reducing ability was used as a second reducing method for 2,6-quinolinediol. For this purpose, $0.01 \mathrm{M}, 0.5 \mathrm{~mL}$ of $\mathrm{CuCl}_{2}$ solution, $0.5 \mathrm{~mL}, 7.5 \times 10^{-3} \mathrm{M}$ neocuproine solution and $1 \mathrm{M}, 0.5 \mathrm{~mL}$ of $\mathrm{NH}_{4} \mathrm{Ac}$ buffer solution were put in to experimental environment, which contains 2,6-quinolinediol at 10 and $20 \mu \mathrm{g} \mathrm{mL}^{-1}$ concentrations. Finally, the volume was completed to $4 \mathrm{~mL}$ with pure water. Absorbance of samples was recorded at $450 \mathrm{~nm}$ after 35 min (Gulcin et al., 2010).

\section{$\mathrm{Fe}^{3+}$ Reducing Power Assay}

For this method, 10 and $20 \mu \mathrm{g} \mathrm{mL}$ concentrations of 2,6-quinolinediol in $1.5 \mathrm{~mL}$ of pure water were added with $2.5 \mathrm{~mL}$ of $0.2 \mathrm{M}, \mathrm{pH}$
6.6 phosphate buffer and $2.5 \mathrm{~mL}$ of potassium ferricyanide(III) (1\%). This mixture incubated at $50^{\circ} \mathrm{C}, 20 \mathrm{~min}$. Then, in test tube, $2.5 \mathrm{~mL}$ of TCA was added. $1 \mathrm{~mL}$ of $\mathrm{FeCl}_{3}(0.1 \%)$ was added to this mixture and the absorbance values were measured at $700 \mathrm{~nm}$ (Topal et al., 2016).

\section{Superoxide Anion Rradical Scavenging Activity}

Superoxide radicals $\left(\mathrm{O}_{2}{ }^{-*}\right)$ scavenging activity of 2,6-quinolinediol was performed in accordance with the method of Zhishen et al. (1999) with slightly modification (Gulcin et al., 2005). $20 \mathrm{~W}$ of fluorescent lamp was stimulated in this experiment. All of this assay was prepared in $0.05 \mathrm{M}, \mathrm{pH} 7.8$ phosphate buffer. This test medium was applied using a $20 \mathrm{~W}$ fluorescent lamp. To the buffer solution containing 2,6-quinolediol was added at certain concentrations from methionine, NBT and riboflavin. The test tubes were incubated for 45 minutes at $25^{\circ} \mathrm{C}$ in $20 \mathrm{~W}$ light environment. The absorbances were measured at $560 \mathrm{~nm}$ (Aksu et al., 2015).

\section{DPPH Scavenging Activity}

This radical removal method was performed according to Gulcin et al. (2010). Briefly, fresh solution of DPPH $(0.1 \mathrm{mM})$ was prepared in ethanol, and $0.5 \mathrm{~mL}$ of this solution was added to $1.5 \mathrm{~mL}$ of 2,6- quinolinediol solution in ethanol at different concentrations (10-20 $\left.\mu \mathrm{g} \mathrm{mL}^{-1}\right)$. These solutions were mixed vigorously and incubated in dark for $30 \mathrm{~min}$. Then, the absorbance value was recorded at 517 $\mathrm{nm}$ in a spectrophotometer (Gulcin, 2005; Gulcin et al., 2005).

\section{ABTS $^{-+}$Scavenging Activity}

$\mathrm{ABTS}^{\circ+}$ scavenging activity of 2,6quinolediol was done using the spectrophotometric method of Re et al. (1999). The ABTS $^{\circ+}$ was acquired by reacting $7 \mathrm{mM}$ solution of ABTS with $2.45 \mathrm{mM} \mathrm{K} \mathrm{S}_{2} \mathrm{O}_{8}$, stored in the dark at room temperature for $6 \mathrm{~h}$. The 
ABTS radical cation solution was diluted with ethanol to an absorbance of $0.750 \pm 0.05$ at 734 $\mathrm{nm}$. Then, $1 \mathrm{~mL}$ of $\mathrm{ABTS}^{\circ+}$ solution was added to $3 \mathrm{~mL}$ of 2,6-quinolinediol in ethanol at different concentrations $\left(10-20 \mu \mathrm{g} \mathrm{mL}{ }^{-1}\right)$. The extent of decolorization is calculated as percentage reduction of absorbance (Gulcin et al., 2010).

\section{DMPD $^{\circ+}$ Scavenging Activity}

DMPD radical scavenging ability of 2,6quinolinediol was done according to the method described by Fogliano et al. (1999). $0.1 \mathrm{M}$ DMPD was prepared in acetate buffer $(0.1 \mathrm{M}$, $200 \mathrm{~mL}$ and $\mathrm{pH}$ 5.3). DMPD radical was obtained. $0.05 \mathrm{M} \mathrm{FeCl}_{3}$ solution was added to this radical The sample was added to the mixture from different concentrations of the solution. The final volume was added up to $500 \mu \mathrm{L}$ of pure water. After a 10 minute wait, the absorbances were evaluated at $505 \mathrm{~nm}$ (Gulcin et al., 2012).

\section{Bipyridyl Chelating Activity}

$\mathrm{Fe}^{2+}$ chelating activity was performed according to the method determined by Re et al. (Re et al., 1999). For this purpose, the test tubes were transferred $0.125 \mathrm{~mL}$ of $\mathrm{FeSO}_{4}$ solution (2 $\mathrm{mM})$. This solution was added 2,6-quinolediol or standard solutions ( 10 and $20 \mu \mathrm{g} \mathrm{mL}^{-1}$ ). Then 0.5 $\mathrm{mL}$ of Tris-HCl buffer (pH: 7.4) was added and in the dark incubated in for half-hour. Later, 0.5 $\mathrm{mL}$ of a $0.2 \%$ biphiryl solution dissolved in $\mathrm{HCl}$ $(0.2 \mathrm{M})$ was added. The absorbance of the sample containing $1.25 \mathrm{~mL}$ of ethanol and 0.625 $\mathrm{mL}$ of pure water was measured at $522 \mathrm{~nm}$.

\section{RESULTS AND DISCUSSION}

The reduction capacity of the 2,6quinolinediol can be calculated by direct reduction of $\mathrm{Fe}^{+3}$ to $\mathrm{Fe}^{+2}$ (Gulcin et al., 2010). In this bioanalytical method used in antioxidant studies, the yellow color of the prepared solution turns into different green tones due to the

reduction activities of the antioxidants in the environment (Çakmakçı et al., 2015). The 2,6quinolinediol reduction capacity used in the study increases in direct proportion with increasing concentration. The reduction potential of 2,6-quinolinediol was determined by measuring the absorbance of the solutions at different concentrations (10 and $20 \mu \mathrm{g} \mathrm{mL}^{-1}$ ) at $700 \mathrm{~nm}$. The capacity of reducing 2,6quinolinediol ferric ions $\left(\mathrm{Fe}^{3+}\right)$ to ferrous ions $\left(\mathrm{Fe}^{2+}\right)$ was plotted (Table 1). For each standard antioxidant and 2,6-quinolinediol, the absorbance values corresponding to $20 \mu \mathrm{g} \mathrm{mL}^{-1}$ were compared. Comparison of the reduction forces of ferric ions $\left(\mathrm{Fe}^{3+}\right)$ with 2,6-quinolinediol and standard antioxidants at this concentration: BHA (2.433) > 2,6-Quinolinediol (1.432) > BHT (1.364) $>$ Trolox (1.328) $>\alpha$-Tocopherol (0.876) was determined to be. In addition, the high absorbance values shown in Table 1 indicate the high reduction capacity. The results proved that 2,6-quinolinediol had marked $\mathrm{Fe}^{3+}$ reducing ability.

Reduction capacity of 2,6-quinolinediol cupric ions $\left(\mathrm{Cu}^{2+}\right)$ was determined by measuring the absorbance at $450 \mathrm{~nm}$ of solutions of different concentrations (10 and $20 \mu \mathrm{g} \mathrm{mL}^{-1}$ ). The reduction capacity of 2,6-quinolinediol cupric ions $\left(\mathrm{Cu}^{2+}\right)$ was found to increase in direct proportion to concentration. After the graph of reduction of 2,6-quinolinediol solutions and cupric ions $\left(\mathrm{Cu}^{2+}\right)$ of standard antioxidants the absorbance values corresponding to $20 \mu \mathrm{g} \mathrm{mL}^{-1}$ for each standard antioxidant and 2,6quinolinediol were compared (Table 1). The results of 2,6-quinolinediol and standard antioxidants $\left(20 \mu \mathrm{g} \mathrm{mL}^{-1}\right)$, respectively. BHA (1.993) > 2,6-Quinolinediol (1.633) > BHT (1.626) > Trolox (0.456) > $\alpha$-Tocopherol (0.374). 
Table 1. Determining the reducing power of 2,6-Quinolinediol

\begin{tabular}{|c|c|c|c|c|c|c|}
\hline \multirow[b]{2}{*}{ Antioxidants } & \multicolumn{2}{|c|}{$\mathrm{Fe}^{3+}-\mathrm{Fe}^{2+}$ reducing $^{\mathrm{a}}$} & \multicolumn{2}{|c|}{$\mathrm{Cu}^{2+}-\mathrm{Cu}^{+}$reducing ${ }^{\mathrm{a}}$} & \multicolumn{2}{|c|}{$\mathrm{Fe}^{3+}-\mathrm{TPTZ}$ reducing ${ }^{\mathrm{a}}$} \\
\hline & $\begin{array}{l}\text { Absorbans } \\
\left(20 \mu \mathrm{g} \mathrm{mL}^{-1}\right)\end{array}$ & $\mathbf{R}^{2}$ & $\begin{array}{l}\text { Absorbans } \\
\left(20 \mu \mathrm{g} \mathrm{mL}^{-1}\right)\end{array}$ & $\mathbf{R}^{2}$ & $\begin{array}{c}\text { Absorbans } \\
\left(20 \mu \mathrm{g} \mathrm{mL}^{-1}\right)\end{array}$ & $\mathbf{R}^{2}$ \\
\hline ВHA & 2.433 & 0.998 & 1.993 & 0.991 & 2.209 & 0.842 \\
\hline BHT & 1.364 & 0.980 & 1.626 & 0.999 & 1.483 & 0.781 \\
\hline$\alpha$-Tocopherol & 0.876 & 0.998 & 0.374 & 0.996 & 1.779 & 0.925 \\
\hline Trolox & 1.328 & 0.989 & 0.456 & 0.999 & 2.092 & 0.887 \\
\hline 2,6-Quinolinediol & 1.432 & 0.948 & 1.633 & 0.979 & 1.645 & 0.845 \\
\hline
\end{tabular}

a expressed as absorbance values.

The FRAP method is an electron-free method that shows antioxidant activity. In this method, ferric ions $\left(\mathrm{Fe}^{3+}\right)$ are reduced to ferrous ions $\left(\mathrm{Fe}^{2+}\right)$. The resulting ferrous $\left(\mathrm{Fe}^{2+}\right)$ ions form a blue complex with TPTZ. This blue colored complex shows maximum absorbance at $593 \mathrm{~nm}$. According to the 2,6-quinolinediol FRAP method; the capacity to reduce ferric ions $\left(\mathrm{Fe}^{3+}\right)$ to ferrous ions $\left(\mathrm{Fe}^{2+}\right)$ was found to increase in direct proportion to the concentration (Table 1). In addition, comparison of reducing activity according to FRAP method with standard antioxidants of 2,6-quinolinediol was performed: BHA (2.209) > Trolox (2.092) $>\alpha$ Tocopherol (1.779) > 2,6-Quinolinediol (1.645) $>$ BHT (1.483).

DPPH free radical removal activity of 2,6quinolinediol solutions increases in direct proportion to the concentration (Table 2). The 2,6-quinolinediol and the standard antioxidant molecules used exhibited DPPH free radical removal activity, respectively. Trolox $>$ BHA > $\alpha$-tocopherol > BHT > 2,6-quinolinediol. $\mathrm{IC}_{50}$ values were found as $57.75 \mu \mathrm{g} \mathrm{mL}^{-1}$ for 2,6-

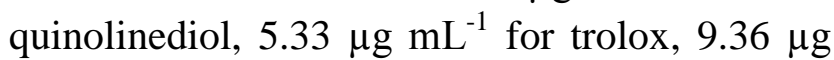
$\mathrm{mL}^{-1}$ for $\alpha$-tocopherol, $31.45 \mu \mathrm{g} \mathrm{mL} \mathrm{m}^{-1}$ for BHT and $8.45 \mu \mathrm{g} \mathrm{mL}^{-1}$ for BHA. A high DPPH. removal activity indicates a low $\mathrm{IC}_{50}$.

$\mathrm{ABTS}^{++}$removal activity, such as DPPH free radical removal activity, is also frequently used in the radical removal activities of aqueous mixtures, beverages, extracts or pure substances (Miller, 1996; Gulcin et al., 2007b). For this purpose, $\mathrm{ABTS}^{\cdot+}$ must be created from ABTS.
After plating the 2,6-quinolinediol $\mathrm{ABTS}^{++}$ radical removal activity for standards and 2,6quinolinediol were calculated $\mathrm{IC}_{50}$ values (Table 2). $\mathrm{ABTS}^{++}$removal activities of 2,6quinolinediol and used standard antioxidant molecules were observed as: BHA > BHT > 2,6quinolinediol $>\alpha$-tocopherol $>$ trolox. The $\mathrm{IC}_{50}$ value for 2,6-quinolinediol in this analysis was $3.39 \mu \mathrm{g} \mathrm{mL}^{-1}$. The concentration of $\mathrm{ABTS}^{\circ+}$ appears to be significantly reduced due to the cleavage ability at different concentrations of 2,6-quinolinediol. Moreover, $\mathrm{IC}_{50}$ values for BHT, BHA, $\alpha$-tocopherol and trolox were found to be $3.36 \mu \mathrm{g} \mathrm{mL}^{-1}, 2.59 \mu \mathrm{g} \mathrm{mL}^{-1}, 4.44 \mu \mathrm{g} \mathrm{mL}^{-1}$ and $7.07 \mu \mathrm{g} \mathrm{mL}^{-1}$, respectively.

If the principle of $\mathrm{DMPD}^{\circ+}$ operation is used at acidic $\mathrm{pH}$ and appropriate oxidant solution, DMPD may form a stable and colored radical cation. $\mathrm{DMPD}^{\circ+}$ indicates the maximum absorbance value at $505 \mathrm{~nm}$ (Garibov et al., 2016). The $\mathrm{DMPD}^{\circ+}$ method provides a very constant end point according to the $\mathrm{ABTS}^{\circ+}$ scavenging method. The main disadvantage of DMPD $^{\circ}+$ was reported to be significantly reduced in terms of sensitivity and renewability if standard antioxidants such as $\alpha$-tocopherol or BHT were used. Therefore, these compounds are not suitable for use in the DMPD ${ }^{\circ+}$ sweep assay. (Gulcin, 2012; Halliwell, 1997; Göçer and Gulcin, 2011).

In DMPD $^{\circ+}$ scavenging assay of 2,6quinolinediol was as effective as in other methods. $\mathrm{IC}_{50}$ value for 2,6-quinolinediol was found as $15.50 \mu \mathrm{g} \mathrm{mL}^{-1}$. This value was found as 
$15.40 \mu \mathrm{g} \mathrm{mL}^{-1}$ for BHA, and $10.04 \mu \mathrm{g} \mathrm{mL}^{-1}$ for trolox (Table 2). BHT and $\alpha$-tocopherol didn't show activity in this assay (Köksal et al., 2009, Gulcin et al., 2012). There was a significant decrease in $\mathrm{DMPD}^{\circ+}$ concentration owing to the scavenging ability of 2,6-quinolinediol concentrations.

Table 2. Determination of $\mathrm{IC}_{50}\left(\mu \mathrm{g} \mathrm{mL} \mathrm{L}^{-1}\right)$ of 2,6-Quinolinediol and standard radical scavenging activities

\begin{tabular}{|c|c|c|c|c|c|}
\hline Antioxidants & $\begin{array}{c}\text { Bipyridyl } \mathrm{Fe}^{2+} \\
\text { chelating }\end{array}$ & $\begin{array}{c}\text { DPPH· } \\
\text { scavenging }\end{array}$ & $\begin{array}{c}\text { ABTS }^{*+} \\
\text { scavenging }\end{array}$ & $\begin{array}{c}\text { DMPD }^{\cdot+} \\
\text { scavenging }\end{array}$ & $\mathrm{O}_{2}-$ scavenging \\
\hline BHA & 36.47 & 08.45 & 02.59 & 15.40 & 14.74 \\
\hline BHT & 05.25 & 31.45 & 32.36 & -* & 43.31 \\
\hline$\alpha$-Tocopherol & 25.67 & 09.36 & 04.44 & $-*$ & 28.88 \\
\hline Trolox & 63.00 & 05.33 & 07.07 & 10.04 & 40.76 \\
\hline 2,6-Quinolinediol & 04.10 & 57.75 & 03.39 & 16.50 & 08.06 \\
\hline
\end{tabular}

*: BHT or $\alpha$-Tocopherol didn't show activity in this assay.

In this context, 2,6-quinolinediol was also effective in the bipyridyl chelating method (Table 2). EDTA is used as a metal chelator. Accordingly, the $\mathrm{IC}_{50}$ values are calculated and listed as follows: EDTA $\left(2.78 \mu \mathrm{g} \mathrm{mL}^{-1}\right)<2,6-$ quinolinediol $\left(4.10 \mu \mathrm{g} \mathrm{mL}^{-1}\right)<\operatorname{BHT}(5.25 \mu \mathrm{g}$ $\left.\mathrm{mL}^{-1}\right)<\alpha$-Tocopherol $\left(25.67 \mu \mathrm{g} \mathrm{mL}^{-1}\right)<$ BHA $\left(36.47 \mu \mathrm{g} \mathrm{mL} L^{-1}\right)<$ Trolox $\left(63.00 \mu \mathrm{g} \mathrm{mL}{ }^{-1}\right)$. According to the results, it was observed that the bipyridyl metal chelating effect of 2,6quinolinediol was higher than the standard antioxidants.

The 2,6-quinolinediol $\mathrm{O}_{2}{ }^{\circ-}$ removal activity was based on the riboflavin / methionine / light method (Gulcin et al., 2004c). The 2,6quinolinediol and standard antioxidant molecules used for superoxide anion radical removal activities were found to be 2,6-quinolinediol > BHA $>\alpha$-tocopherol $>$ trolox $>$ BHT, respectively. When we seem $\mathrm{O}_{2}{ }^{-}$radical scavenging activity results, it was determined that $\mathrm{O}_{2}{ }^{-}$cleaning activity of 2,6-quinolinediol was higher than standard compounds. As shown in Table 2, the $\mathrm{IC}_{50}$ value of 2,6-quinolinediol was $8.06 \mu \mathrm{g} \mathrm{mL}^{-1}$. According to these results, the $\mathrm{IC}_{50}$ values of antioxidants, which are preferred as synthetic antioxidants, are much higher than the substances in our study. In comparison with a natural antioxidant $\alpha$-tocopherol, its $\mathrm{IC}_{50}$ value was $28.88 \mu \mathrm{g} \mathrm{mL}^{-1}$ and the 2,6-quinolinediol was found to be $8.06 \mu \mathrm{g} \mathrm{mL}^{-1}$. A substance must be effective at low concentration to be an antioxidant. 2,6-quinolinediol was manifest by the results obtained in this regard.

\section{CONCLUSION}

When the results were evaluated, in the 8 different antioxidant methods, 2,6 quinolindiol showed antioxidant effect which was more effective or closer than the standard antioxidants. The positive results of both reductions and reduction capacities showed that 2,6quinolindiol compound could be preferred as antioxidant. In this case, it is thought that our material may shed light on the works in the field.

\section{REFERENCES}

Aksu K, Topal F, Gulcin I, Tümer F, Göksu S, 2015. Acetylcholinesterase inhibitory and antioxidant activities of novel symmetric sulfamides derived from phenethylamines. Archiv der Pharmazie, 348 (6): 446-455.

Alho H, Leinonen J, 1999. Total antioxidant activity measured by chemiluminescence methods. Methods in Enzymology, 299, 315. 
Apak R, Güçlü K, Özyürek M, Karademir SE, 2004. A novel total antioxidant capacity index for dietary polyphenols, vitamin $\mathrm{C}$ and $\mathrm{E}$, using their cupric ion reducing capability in the presence of neocuproine: The CUPRAC method. Journal of Agricultural and Food Chemistry, 52:7970-7981.

Bursal E, Köksal E, Gulcin I, Bilsel G, Gören AC, 2013. Antioxidant activity and polyphenol content of cherry stem (Cerasus avium L.) determined by LC-MS/MS. Food Research International, 51(1): 66-74.

Çakmakçı S, Topdaş EF, Kalın P, Han H, Şekerci P, Polat Kose L, Gulcin I, 2015. Antioxidant capacity and functionality of oleaster (Elaeagnus angustifolia L.) flour and crust in a new kind of fruity ice cream. International Journal of Food Science Technology, 50 (2):472-481.

Davies KJ, 1995. Oxidative stress: the paradox of aerobic life. Biochemical Society Symposium, 61, 1-31.

Dinis TCP, Madeira VMC, Almeida LM, 1994. Action of phenolic derivatives (acetaminophen, salicylate, and 5aminosalicylate) as inhibitors of membrane lipid peroxidation and as peroxyl radical scavengers. Arch Biochem Biophys. 315:161-169.

Eberhardt MV, Lee CY, Liu RH, 2000. Antioxidant activity of fresh apples. Nature, 405(6689): 903-904.

Fessenden RJ, Fessenden JS, Logue MW, 2001. Organic Chemistry, $6^{\text {th }}$ edition, pp. 808. Güneş Kitabevi, Ankara-Turkey.

Fogliano V, Verde V, Randazzo G, Ritieni A. 1999. Method for measuring antioxidant activity and its application to monitoring the antioxidant capacity of wines. Journal of Agricultural and Food Chemistry, 47(3):1035-1040.
Garibov E., Taslimi P, Sujayev A, Bingöl Z, Çetinkaya S, Gulcin I, Beydemir S, Farzaliyev V, Alwasel SH, Supuran CT, 2016. Synthesis of 4,5-disubstituted-2thioxo-1,2,3,4-tetrahydropyrimidines and investigation of their acetylcholinesterase, butyrylcholinesterase, carbonic anhydrase I/II inhibitory and antioxidant activities. Journal of Enzyme Inhibition and Medicinal Chemistry, 31(S3): 1-9.

Göçer H, Gulcin I, 2011. Caffeic acid phenethyl ester (CAPE): Correlation of structure and antioxidant properties. International Journal of Food Science Nutrion, 62(8):821-825.

Gulcin I, 2005. The antioxidant and radical scavenging activities of black pepper (Piper nigrum) seeds. International Journal of Food Science Nutrion, 56(7):491-499.

Gulcin I, 2007. Comparison of in vitro antioxidant and antiradical activities of L-tyrosine and L-Dopa. Amino Acids, 32(3): 431-438.

Gulcin I, 2010. Antioxidant properties of resveratrol: A structure-activity insight. Innovative Food Science and Emerging Technologies, 11(1): 210-218.

Gulcin I, 2012. Antioxidant activity of food constituents-An overview. Archives of Toxicology, 86(3):345-391.

Gulcin I, Beydemir S, Sat İG, Kuvrevioglu Öİ, 2005. Evaluation of antioxidant activity of cornelian cherry (Cornus mas L.). Acta Aliment Hung. 34(2):193-202.

Gulcin I, Beydemir S, Topal F, Gagua N, Bakuridze A, Bayram R, Gepdiremen A, 2012. Apoptotic, antioxidant and antiradical effects of majdine and isomajdine from Vinca herbacea Waldst. and kit. Journal of Enzyme Inhibition Medicinal Chemistry, 27(4):587-594.

Gulcin I, Elias R, Gepdiremen A, Boyer L, Köksal E, 2007b. A comparative study on the antioxidant activity of fringe tree (Chionanthus virginicus L.) extracts. African Journal of Biotechnology, 6(4): 410-418. 
Gulcin I, Elias R, Gepdiremen A, Chea A, Topal F, 2010. Antioxidant activity of bisbenzylisoquinoline alkaloids from Stephania rotunda: Cepharanthine and fangchinoline. Journal of Enzyme Inhibition Medicinal Chemistry, 25(1):44-53.

Gulcin I, Mshvildadze V, Gepdiremen A, Elias R, 2004c. Antioxidant activity of saponins isolated from ivy: $\alpha$-Hederin, hederasaponin$\mathrm{C}$, hederacolchiside-E and hederacolchiside F. Planta Medica, 70(6): 561-563.

Gulcin I, Şat İG, Beydemir Ş, Elmastaş M, Küfrevioğlu Öİ, 2004. Comparison of antioxidant activity of clove (Eugenia caryophylata Thunb) buds and lavender (Lavandula stoechas L.). Food Chemistry, 87:393-400.

Gulcin I, Topal F, Çakmakçi R, Gören AC, Bilsel M, Erdoğan U, 2011. Pomological features, nutritional quality, polyphenol content analysis and antioxidant properties of domesticated and three wild ecotype forms of raspberries (Rubus idaeus L.). Journal of Food Science, 76:C585-C593.

Halliwell B, 1997. Antioxidants in human health and disease. Annual Review of Nutrition, 16: 33-50.

Hart H, Craine LE, Hart, DJ, Hadad CM, 2011. Organic Chemistry, $12^{\text {th }}$ edition, pp.393-394, Palme Publishing, Ankara-Turkey.

Hudson JF, 1990. Food antioxidants. Elsevier Applied Food Science, London.

Köksal E, Gulcin I, Öztürk Sarıkaya SB, Bursal E. 2009. On the in vitro antioxidant activity of silymarine. Journal of Enzyme Inhibition Medicinal Chemistry, 24(2):395-405.

Miller DD, 1996. Minerals. In "Food Chemistry", O.R. Fennema (Ed), pp: 617-649. Marcel Dekker, New York.

Öztaşkın N, Çetinkaya Y, Taslimi P, Göksu S, Gulcin I, 2015. Antioxidant and acetylcholinesterase inhibition properties of novel bromophenol derivatives. Bioorganic Chemistry, 60: 49-57.
Ökten S, Eyigün D, Çakmak O, 2015. Synthesıs of Brominated Quinolines. Journal of Engineering and Natural Sciences, Sigma 33, 8-15.

Re R, Pellegrini N, Proteggente A, Pannala A, Yang M, Rice-Evans C, 1999. Antioxidant activity applying an improved ABTS radical cation decolorization assay. Free Radical Biology and Medicine, 26(9-10):1231-1237.

Sherwin ER, 1990. In: Branen, A.L., Davidson, P.M., Salminen, S., (eds) Food additives, Marvel Dekker Incorporated, 139-193, New York.

Taslimi P, Gulcin I, 2018. Antioxidant and anticholinergic properties of olivetol. Journal of Food Biochemistry, 42(3), e12516.

Topal F, Topal M, Gocer H, Kalin P, Kocyigit UM, Gulcin I, Alwasel SH, 2016. Antioxidant activity of taxifolin: an activitystructure relationship, Journal of Enzyme Inhibition and Medicinal Chemistry, 31(4): 674-683.

Topal M, 2018. Determination of antioxidant and antiradical properties of Picea orientalis cone. Anadolu Journal of Agricultural Sciences, 33: 232-236.

Wichi HP, 1988. Enhanced tumour development by butylated hydroxyanisole (BHA) from the perspective of effect on forestomach and oesophageal squamous epithelium. Food and Chemical Toxicology, 26: 717-723.

Zhishen J, Mengcheng T, Jianming W, 1999. The determination of flavonoid contents in mulberry and their scavenging effects on superoxide radicals. Food Chemistry, 64:555-559. 